\title{
Utilization of Moringa oleifera as Natural Coagulant for Water Purification
}

\author{
Meng Hong Ng${ }^{1}$, Mohamed Soliman Elshikh ${ }^{2}$ \\ ${ }^{1}$ Environmental Engineering Program, Faculty of Engineering and Science, Curtin University Malaysia, CDT 250, Miri, \\ Malaysia \\ ${ }^{2}$ Department of Botany and Microbiology, College of Sciences, King Saud University, P.O. Box 22452, Riyadh 11495, Saudi \\ Arabia. \\ *Correspondence: ngmenghong9@gmail.com
}

SUBMITTED: 1 November 2021; REVISED: 29 November 2021; ACCEPTED: 30 November 2021

\begin{abstract}
The plant-based natural coagulant has the potential to substitute the chemical coagulant in the water treatment process. In this work, the potential of plant-based natural coagulants in the ability of turbidity removal was identified. The Moringa oleifera seed was selected for the batch analysis test such as $\mathrm{pH}$, contact time, agitation, and dosage. The high alkaline water decreases the effectiveness of plant-based natural coagulants. The agitation and contact time show the importance of the coagulation process. The optimum turbidity removal rate in $\mathrm{pH}$ is 4 , the contact time is 60 seconds and 3000 seconds for coagulation and flocculation, respectively, the agitation is 300 RPM and 30 RPM for coagulation and flocculation, and lastly, the dosage is $10 \mathrm{~g}$ of Moringa oleifera seed. Finally, the plant-based natural coagulants demonstrated the ability to remove turbidity and could be used in place of chemical coagulants.
\end{abstract}

KEYWORDS: plant-based natural coagulant; Moringa oleifera seed ; turbidity removal; water purification

\section{Introduction}

Water is one of the major elements of life, and about $70 \%$ of the human body is water. Therefore, water is a necessary and indispensable substance for life. Although the water covers more than $70 \%$ on the Earth's surface, $97.5 \%$ of the water on the earth consider is seawater, and fresh water only contribute for $2.5 \%$. In this $2.5 \%$ of fresh water, $70 \%$ is frozen in polar glaciers, leaving nearly $30 \%$ in deep groundwater source. Therefore, only less than $1 \%$ of fresh water is available for direct use. In short, only about $0.025 \%$ of all water is the water that can be used. Fresh water resources are very rare and precious [1,2]. Typical water treatment are physical treatment and chemical treatment. The physical method includes use of different filter materials with different pore sizes to achieve the filtration effect. The adsorption method is used to exclude the impurities in water with activated carbon. The physical method is allowed the water pass through the filter material, so the bulky impurities are blocked and thus the fresh water is obtained. The chemical method is using various chemicals to convert the impurities in water into less hazard effect to human body or concentrate the impurities [3]. 
The identification potential of animal-based coagulants and plant-based natural coagulants was challenging due to a lack of awareness and information about the chemical composition of tissue behavior on coagulation effect [4]. Some plant-based natural materials were studied, such as Moringa oleifera (MO) and common beans, which contain cationic compounds, while anionic compounds were found in cactus and okra mucilage [5]. Thus, the different composition of the plant-based natural coagulant requires a critical investigation of its applicability. To satisfy the demand for clean water for humans and the environment, the plant-based natural coagulant is the alternative sustainable water purification method to achieve the sustainability development initiative. The aim of this study was to investigate some plantbased natural coagulants for water purification.

\section{Materials and Methods}

\subsection{Materials}

The materials used in this experiment were raw water from Curtin Lake and different natural coagulants such as MO seed, okra seed, papaya seed, soybean and water hyacinth. There are three major steps in extracting the plant-based natural coagulants in this experiment, which are the primary processing step, secondary processing step, and tertiary processing step. The simplest of these three-processing steps is the primary processing step. The primary processing steps include extracting the different parts of the plant, such as its seeds, leaves, stems, kernels, fruits, and other structures as a coagulant. The primary step is easy to apply without any advanced technology. Some of the plant-based natural coagulants can be point of use in water treatment, such as soybean and MO seed. In the secondary processing step, some chemicals are required to perform the extraction of the contaminant from the plant-based natural coagulant. This process offers the opportunity to remove the compounds that impact the efficiency of coagulation. The tertiary process is the most expensive and complex.

\subsection{Extraction protein from plant-based natural coagulants}

The extraction of protein from plant-based natural coagulants was conducted according to modified previous methods [6,7]. The dried plant-based natural coagulants were sieved into fine powder through a sieve shaker. The sieve size for this work was $400 \mu \mathrm{m}$ to $150 \mu \mathrm{m}$. To eliminate the non-coagulant compound from the dried plant-based natural coagulants, the 1.0 $\mathrm{M}$ sodium chloride $(\mathrm{NaCl})$ was prepared by dissolving $58.5 \mathrm{~g}$ in 1 litre of distilled water because the $1.0 \mathrm{M} \mathrm{NaCl}$ was able to extract the protein from the plant-based natural coagulant tissue. Next, the fine powder form of plant-based natural coagulants was added into the $\mathrm{NaCl}$ solution and stirred by the magnetic stirrer for $30 \mathrm{~min}$ at a room temperature of $25{ }^{\circ} \mathrm{C}$. The suspension was filtered with filter paper and dried in the drying and heating chamber at $70{ }^{\circ} \mathrm{C}$ for $12 \mathrm{~h}$. The extracted dry, fine powder was used as the primary coagulant in the jar test experiment.

\subsection{Delipidation and purification extraction process}

The plant-based natural coagulant may contain contaminants, non-coagulant compounds that affect coagulation efficiency, such as lipid, dust, ash, minerals, carbohydrates, and other proteins.Therefore, the delamination and purification extraction were performed to eliminate those non-coagulant compounds. The excessive natural organic matter loading is a major 
setback in the use of natural extracts in water treatment. Therefore, the purification method aims to address the challenge of water quality degradation with natural extract treatment. The fine powder of plant-based natural coagulants was defatted through a delipidation process by using hexane in an electro-thermal or water bath Soxhlet extractor. In this work, the electrothermal device was applied. The electro-thermal device for the Soxhlet extractor was operating at $60{ }^{\circ} \mathrm{C}$ and the best efficiency for extraction was $1 \% \mathrm{w} / \mathrm{v}$ of plant-based natural coagulant sample with hexane. Next, the residues from the electro-thermal Soxhlet extractor were taken out and dried at room temperature, $25{ }^{\circ} \mathrm{C}$. To complete the extraction cycle for delipidation, the color of the extracted liquid should turn transparent $[8,9]$.

\subsection{Jar test}

The jar test is the common process for running the water treatment test [10]. The fundamental principle of the jar test is adding coagulant into the untreated water or contaminated water. The coagulant is an electrolyte and it will form micelles in water, and the colloidal substance in the water will be neutralized, thus forming floc and settling down. The plant-based natural coagulant in defatted and fine powder form will be added to the water during the rapid mixing process. The coagulation and flocculation processes were completed with selective RPM and contact time. The requirements for coagulation are fast and uniform. When a plant-based natural coagulant is added to water, it hydrolyzes and produces an iso-charged colloid, which interacts with the colloid and suspended matter in the water to form floc.Then the mixing speed was reduced to allow the floc to form larger particles and settle down. This process is called flocculation. After the flocculation process, the beaker was removed from the equipment and allowed to stand undisturbed to settle for 1 hour. The treated surface water in the beaker was obtained by using a syringe and run for turbidity and $\mathrm{pH}$ tests by using a turbidity meter and a $\mathrm{pH}$ meter. The condition of batch studies can be summarized in Table 1 . The percentage of turbidity can be calculated using an equation as follows:

Turbidity removal $(\%)=\frac{T_{i}-T_{f}}{T_{f}} \times 100 \%$

where $T_{i}$ is initial turbidity of the water and $T_{f}$ is the final turbidity after the jar test.

Table 1. The condition of batch studies

\begin{tabular}{lcccccc}
\hline \multirow{2}{*}{ Parameters } & \multirow{2}{*}{ Dosage (g) } & \multicolumn{2}{c}{ Contact time (s) } & \multicolumn{2}{c}{ Agitation (rpm) } & \multirow{2}{*}{ pH } \\
\cline { 3 - 6 } & & Coagulation & Flocculation & Coagulation & Flocculation & 7 \\
Effect of dosage & $1-10$ & 20 & 1200 & 150 & 15 & 7 \\
Effect of contact time & 2 & $10-60$ & $600-3000$ & 150 & 15 & 7 \\
Effect of agitation & 2 & 20 & 1200 & $75-300$ & $7-23$ & 7 \\
Effect of pH & 2 & 20 & 1200 & 150 & 15 & $4-9$ \\
\hline
\end{tabular}

\section{Results and Discussion}

\subsection{Screening of the plant-based natural coagulant}

The screening experiment was conducted to determine the highest removal rate of turbidity among all the plant-based natural coagulants, including MO seed, okra seed, papaya seed, water hyacinth, and soybean. The plant-based natural coagulant with the highest removal rate was chosen to proceed with the batch analysis experiment in which different parameters such as $\mathrm{pH}$, contact time (s), and agitation (rpm) were tested. For the screening experiment, the initial 
dosage of each extracted plant-based natural coagulant was kept at $5 \mathrm{~g}$. The contact time for coagulation and flocculation was kept at $20 \mathrm{~s}$ and $1200 \mathrm{~s}$, respectively, while the agitation speed for coagulation and flocculation was kept at $150 \mathrm{rpm}$ and $15 \mathrm{rpm}$. The degree of $\mathrm{pH}$ was kept at 7.50.3 without any adjustment for $\mathrm{pH}$ because, based on Yin (2010), the plant-based natural coagulant will not alter the final $\mathrm{pH}$ of the water after the purification process [11]. Based on Figure 1, both MO extract and okra seed achieved a high turbidity removal rate of more than $80 \%$, which satisfied the water treatment standard as outlined in the National Water Quality Standard for Malaysia (NWQS). The highest turbidity removal rate was achieved by using Moringa oleifera extract as a plant-based natural coagulant, in which it exhibited at least $91.59 \%$, followed by okra seed, with a result of $84.59 \%$. Meanwhile, the soybean exhibited the lowest turbidity removal rate, which was $7.89 \%$. The water hyacinth achieved a $45.88 \%$ turbidity removal rate, followed by papaya seed, which achieved $53.92 \%$ turbidity removal. Hence, the MO was selected to proceed to the batch analysis test and dosage (g) was examined. Based on the existing studies available online, the soybean is exceedingly one of the plantbased natural coagulants with an average turbidity removal rate ranging from $80-95 \%$. However, salt solution extraction and delipidation have destroyed the protein structures of the soybean. The soybean contained a large fraction of lipid and the delipidation removed the lipid from the soybean. Thus, the effectiveness of coagulation was not functioning well [12]. Moreover, the electrostatic interactions between the cations and the soybean protein led to an increase in turbidity. The direct point-of-use of soybean as the plant-based natural coagulant is preferred without any purification of its plant structure [9].

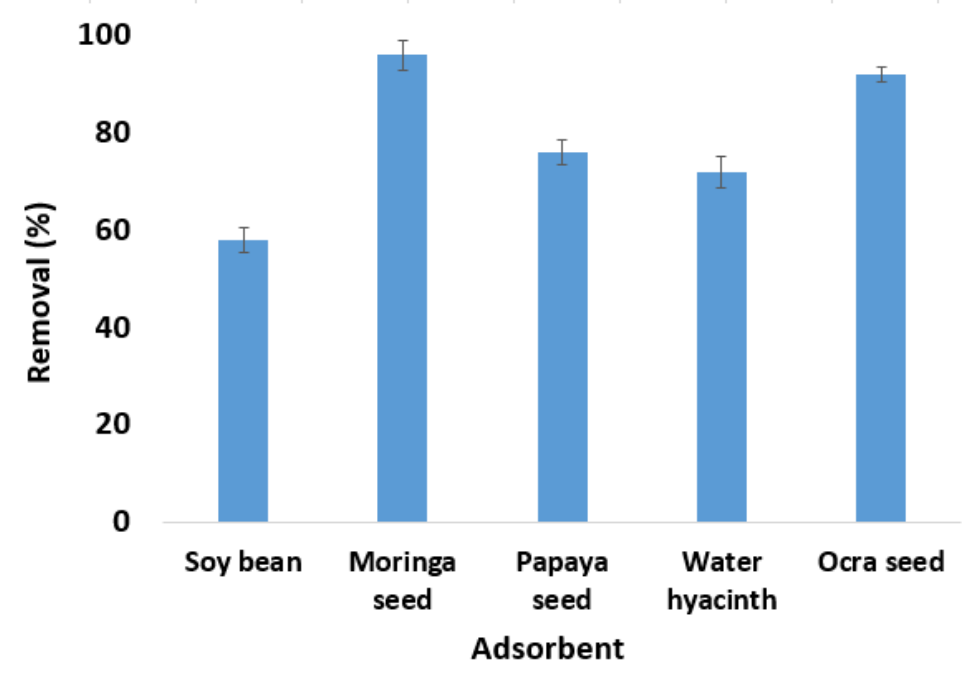

Figure 1. The graph of screening result.

\subsection{The effect of $p H$}

This experiment has been conducted to determine the effect of $\mathrm{pH}$ on the turbidity removal rate. The initial $\mathrm{pH}$ of the raw water from Curtin Lake Site was adjusted with sodium hydroxide $(\mathrm{NaOH})$ and hydrochloric acid $(\mathrm{HCl})$ to 4,6 , and 9 for each $500 \mathrm{ml}$ of water. At $2 \mathrm{~g}$ of plantbased natural coagulant, agitation was set to $150 \mathrm{rpm}$ for coagulation and $15 \mathrm{rpm}$ for flocculation, with contact time set to $20 \mathrm{~s}$ for coagulation and $20 \mathrm{~min}$ for flocculation. Figure 2 shows that the MO extract turbidity removal rate for turbidity under different $\mathrm{pH}$ conditions. The result shows that a higher $\mathrm{pH}$ value has a lower turbidity removal rate. Different $\mathrm{pH}$ values 
were employed to test the stability of protein in plant-based natural coagulants. The turbidity removal rate was decreased when the $\mathrm{pH}$ value was more alkaline. The highest turbidity removal rate was $64.25 \%$ in the condition of $\mathrm{pH} 4$, while the lowest was $27.90 \%$ in the condition of $\mathrm{pH}$ 9. Based on Figure 2, it can be concluded that the degree of $\mathrm{pH}$ is inversely proportional to the turbidity removal rate. The protein stability decreases with alkaline conditions; therefore, the removal rate is decreased. However, it is not practically possible to treat the water in such a low $\mathrm{pH}$ condition because it requires additional resources by local authorities to adjust the $\mathrm{pH}$ to achieve the acceptable $\mathrm{pH}$ level of 6.5 to 7.5.

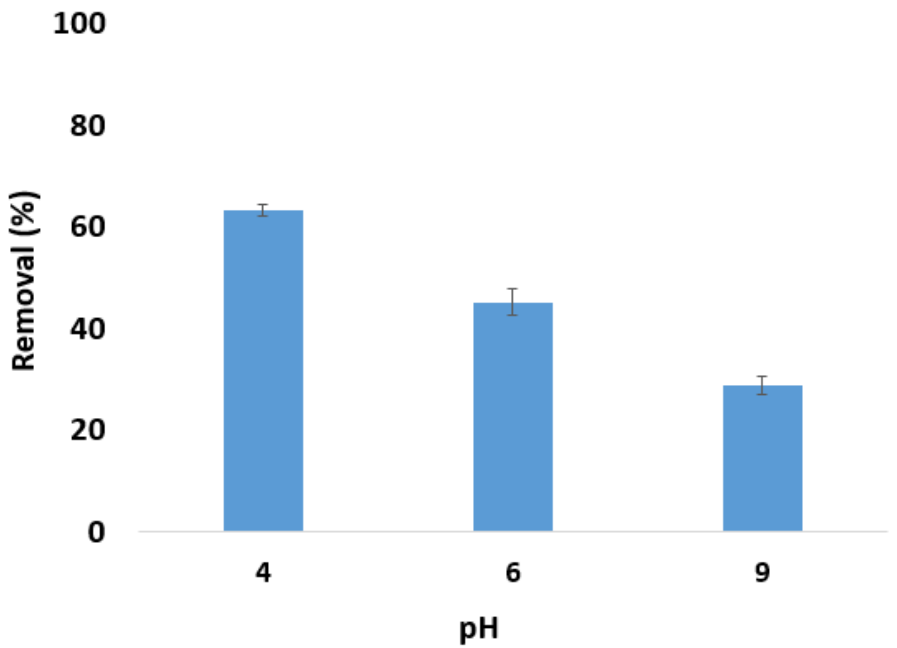

Figure 2. The effect of $\mathrm{pH}$ on turbidity removal rate by Moringa oleifera extract.

Moreover, the result was supported by Jones (2017) with a turbidity result of 98\%, 65\%, and

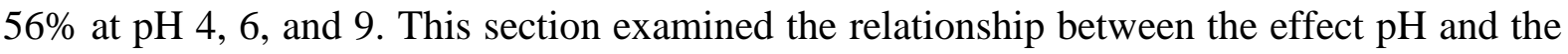
buffering effect of the reaction between carboxyl-COOH-and amino $\left(\mathrm{NH}_{2}\right)$ in the plant-based natural coagulant seed protein. The buffer capacity is estimated to be 0.017 for MO extract [13]. A minor change in final $\mathrm{pH}$ after the water treatment may also be due to the balancing of hydrogen ions in the plant-based natural coagulant seed with the raw water hydroxide ions [14]. Although some previous studies have shown that the most effective turbidity removal rate for coagulation by the effect of $\mathrm{pH}$ is above the neutral $\mathrm{pH}$ value [15]. This section is to investigate the effects of different $\mathrm{pH}$ values on the performance of Moringa seed extract. Conventional water treatment methods use chemical coagulants such as ferric sulfate $\left[\mathrm{Fe}_{2}\left(\mathrm{SO}_{4}\right)_{3}\right]$ to remove the turbidity in raw water intake. The chemical coagulant applied could affect the residual colloids in the water, which will affect the $\mathrm{pH}$ in the treated water and increase the residual health effects on humans. However, the use of plant-based natural coagulants has been reported in many studies and research that it does not affect the final $\mathrm{pH}$ of the water [11]. The $\mathrm{pH}$ value is one of the factors that affects the result of the coagulation and flocculation processes. Each of the plant-based natural coagulants has a different optimum $\mathrm{pH}$ value. Based on the studies, the optimum $\mathrm{pH}$ for $\mathrm{MO}$ extract as a plant-based natural coagulant was somewhere between $\mathrm{pH} 6$ and 8. At the optimum $\mathrm{pH}$ value, the protein from $\mathrm{MO}$ will ionize to produce carboxylate ions and protons to attract colloids to form neutral groups that will eventually become floc [16]. 


\subsection{The effect of dosage}

The water treatment process in the jar test contains two primary destabilization mechanisms, which are charge neutralization and sweep flocculation. The coagulation mechanism is dependent upon the plant-based natural coagulant dosage. In the charge neutralization, the positive charged of protein from plant-based natural coagulants is attracted to the negative charge colloid via electrostatic interaction. The dosage of the plant-based natural coagulant has significant effect on the optimum capacity of turbidity removal. Moreover, insufficient dosage of plant-based natural coagulant will not effectively destabilize the particles in the water while excessive dosage of plant-based natural coagulant can result in detrimental impact. This experiment has been conducted to determine the effect of dosage on the turbidity removal rate. The dosage of MO extract as plant-based natural coagulants added into the raw water were chosen to be $1 \mathrm{~g}, 3 \mathrm{~g}$, and $10 \mathrm{~g}$. Each of the MO extract was added into $500 \mathrm{ml}$ of water for jar test experiment with the agitation speed of $150 \mathrm{rpm}$ for coagulation and $15 \mathrm{rpm}$ for flocculation; while the contact time was decided to be $20 \mathrm{~s}$ for coagulation and $1200 \mathrm{~s}$ (20 min) for flocculation. Figure 3 represent the effect of dosage on the turbidity removal rate by the MO extract. The overall turbidity removal rate achieved were more than $90 \%$. The effect of plantbased natural coagulant dosage was evaluated during the jar test experiment with different dosage of MO extract from 1 gram, 3 grams and 10 grams. The turbidity removal rate for Curtin Lake Site water was increased from $90.58 \%$ to $94.89 \%$. The $10 \mathrm{~g}$ of MO extract achieved the highest turbidity removal rate of $94.89 \%$ while $3 \mathrm{~g}$ of MO extract achieved $93.29 \%$ of turbidity removal rate and lastly $1 \mathrm{~g}$ of MO extract achieved lowest turbidity removal rate of $90.58 \%$.

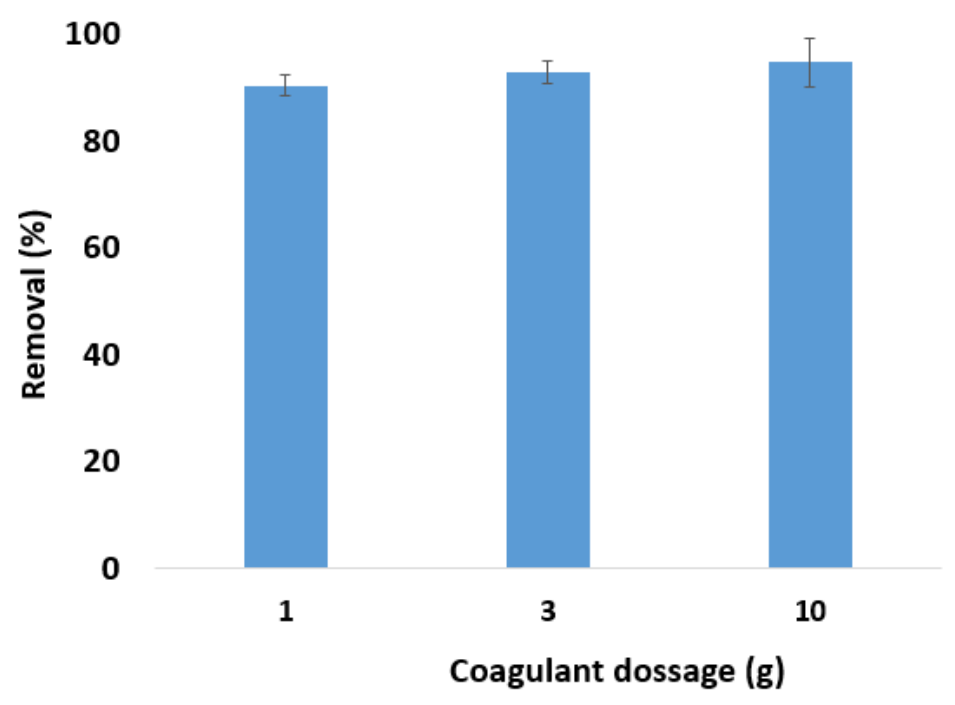

Figure 3. The effect of coagulant dosage on turbidity removal rate.

It can be concluded that the dosage of plant-based natural coagulants is directly proportional to the turbidity removal rate. The increasing dosage can achieve a higher turbidity removal rate. The amount of MO extract is increasing the number of proteins in the water, thus increasing the binding between the flocs. The number of proteins has increased the effectiveness of charge neutralization in the water; thus, the turbidity removal has increased [17]. Based on Figure 4, the $10 \mathrm{~g}$ of MO extract has a fine and soft precipitate. However, the 1 
$\mathrm{g}$ of MO extract has a coarse precipitate. It can be concluded that the insufficient dosage of plant-based natural coagulant was not able to destabilize all the particles in the water. A previous study showed that the relationship between the number of dosages of plant-based natural coagulant and the turbidity removal rate in which the turbidity removal rate was achieved was all more than $90 \%$ for dosages of 5 to $35 \mathrm{~g}$ of plant-based natural coagulants [18]. Moreover, it is important to study the effect of dosage to save the cost of preventing overdosing in coagulant applied in water treatment. Not only that, the high amount of dosage in plant-based natural coagulant applied in water treatment poses a great possibility in the destabilized particles in which re-stabilization will likely occur due to the high concentration of the polymer bridge [17].

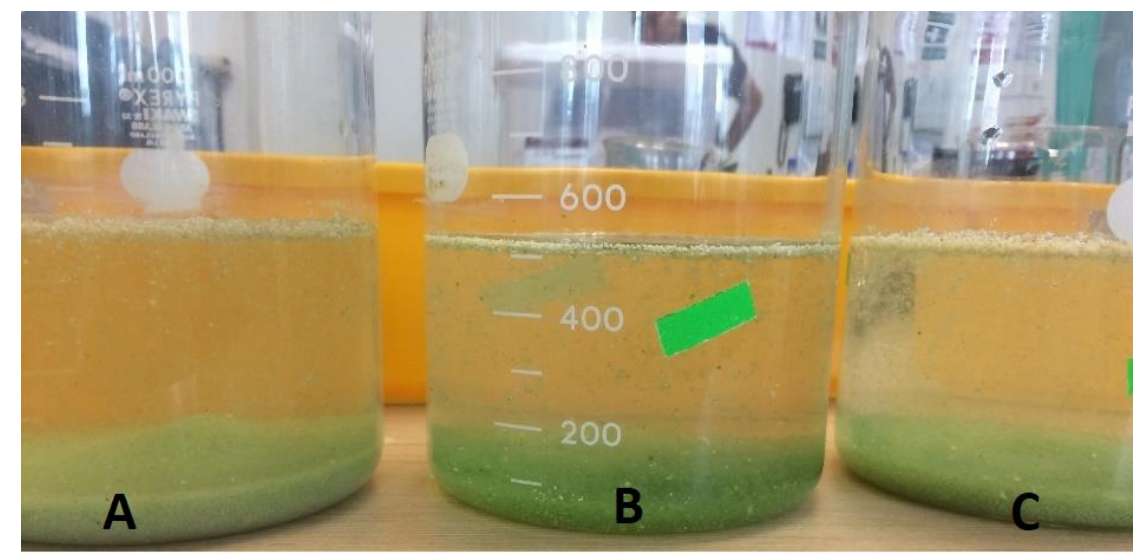

Figure 4. The effect of dosage: (A) $10 \mathrm{~g}$ of $\mathrm{MO}$ extract (B) $1 \mathrm{~g}$ of $\mathrm{MO}$ extract (C) $3 \mathrm{~g}$ of $\mathrm{MO}$ extract.

\subsection{The effect of agitation}

The agitation speed is one of the factors that affects the coagulation-flocculation process efficiency during the jar test experiment. The jar test was performed to evaluate the agitation effect on the turbidity removal rate of Curtin Lakeside water by the MO extract as a plantbased natural coagulant. The dosage for each set was kept at $2 \mathrm{~g}$ of MO extract as a plant-based natural coagulant, while the contact time for coagulation and flocculation was kept constant at $20 \mathrm{~s}$ and $1 \mathrm{~min}(20 \mathrm{~min})$ for each set. The degree of $\mathrm{pH}$ remained neutral. This test is to determine the optimum agitation speed for the stability of the protein charge of MO extract to form floc. The effect of agitation speed was evaluated with different set-ups. It is noted that set 1 with the agitation speed of $75 \mathrm{rpm}$ and $7 \mathrm{rpm}$ exhibited zero effect on the turbidity removal rate. Based on Figure 5, since the result from set 2 was close to the result from set 3 , it can be concluded that the optimum agitation speed for the turbidity removal rate was between the range of 225 to 300 for coagulation and 23 to 30 for flocculation. It can be concluded that the specific agitation speed had a significant effect on the turbidity removal rate by the plant-based natural coagulant.

Therefore, the large floc was so fragile that instead of binding together, they constantly repelled each other and tended to float in the water. Previous studies stated that the minimum agitation speed required for plant-based natural coagulant was $80 \mathrm{rpm}$ for coagulation in order to prevent floc fragility that causes loss of effectiveness in turbidity removal [19,20]. Another study showed that the increase in agitation speed also increases the efficiency of turbidity removal rate, with a result of $98 \%$ for the MO extract [21]. However, the dosage applied in 
their research was $0.2 \mathrm{~g}$ per liter of MO extract, with 0.21 of $1 \mathrm{~g} / 1$ sorbate solution to run the experiment. Furthermore, Jaoudi and Amdouni stated that the low agitation speed could result in floc fragility with an agitation speed of less than $80 \mathrm{rppm}$. The floc formed during the jar text experiment was easily broken and the turbidity removal rate was decreased [20].

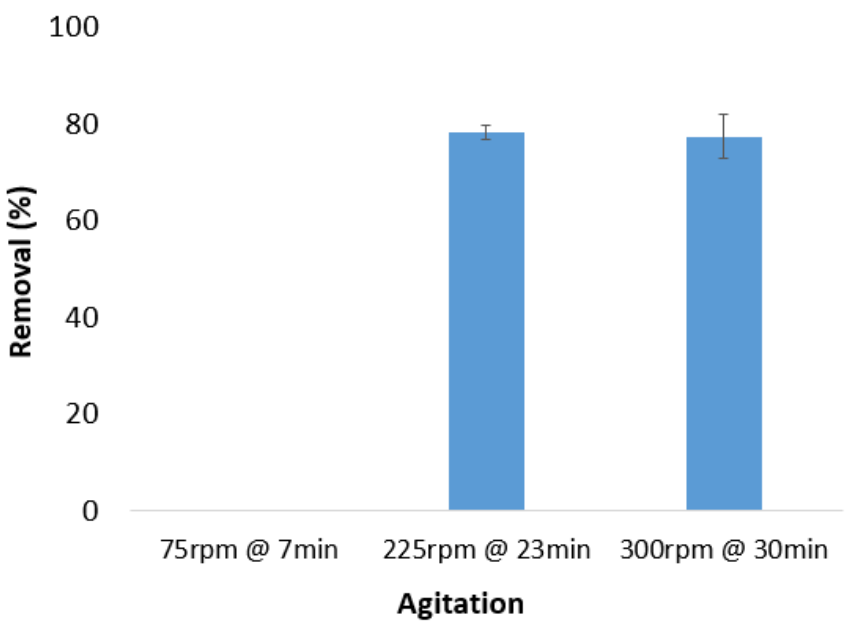

Figure 5. Effect of agitation on Turbidity removal rate.

\subsection{The effect of contact time}

Contact time is a parameter for determining the equilibrium time required for the coagulation and flocculation processes in the jar test experiment. The jar test was performed to evaluate the contact time effect on the water turbidity removal rate by the MO extract as the plant-based natural coagulant. The variables were decided to be 3 sets in which contact time was $10 \mathrm{~s}$ for coagulation and $600 \mathrm{~s}$ (10 min) for flocculation; $40 \mathrm{~s}$ for coagulation and $1800 \mathrm{~s}$ (30 min) for flocculation; and $60 \mathrm{~s}$ for coagulation and $3000 \mathrm{~s}(50 \mathrm{~min})$ for flocculation, accordingly. This test is to determine the optimum contact time for the formation of floc. The effect of contact time was evaluated during the jar test experiment. The turbidity removal rate for the Curtin Lake Site increased with the contact time. Set 1 exhibited a zero-turbidity removal rate, while sets 2 and 3 exhibited significant positive effects on the turbidity removal rate with $57.97 \%$ and $69.11 \%$, respectively. The highest turbidity removal rate was obtained in set 3, which was $69.11 \%$, while the lowest turbidity removal rate was obtained in set 1 , which was $0 \%$. Moreover, based on Figure 6, it can be concluded that rapid mixing requires a minimum amount of contact time to prevent insufficient mixing. However, increases in contact time will improve the effectiveness of the coagulation process.

The short time for coagulation was not enough to disperse the protein from Moringa oleifera. Thus, the effectiveness of the neutralization of charge in the water was greatly affected by insufficient mixing, as stated by Cai and Chang [22]. Therefore, set 1 exhibited no significant effect on the turbidity removal rate due to the fragility of the floc formation. Sasikala and Muthuraman proved that the increases in settling time for flocculation will result in an increased turbidity removal rate [18]. 


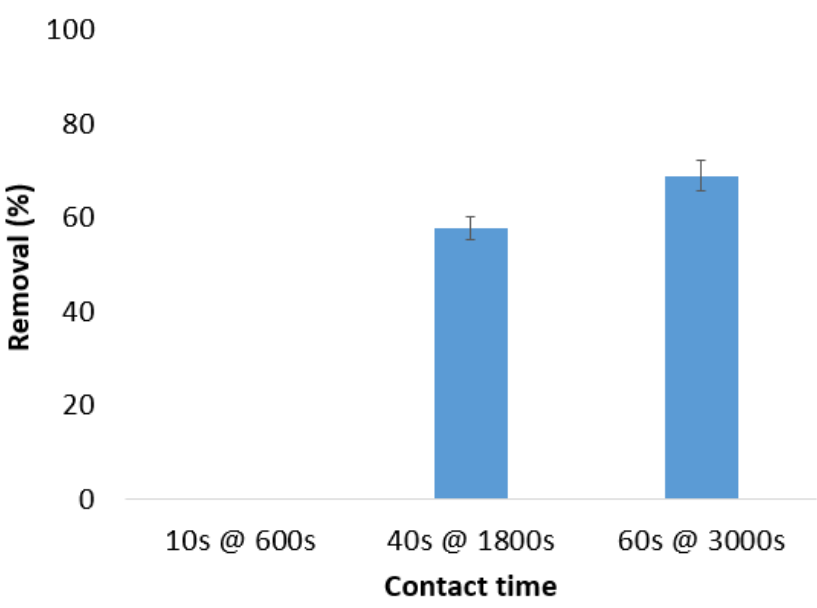

Figure 6. Effect of contact time on the turbidity removal rate.

\section{Conclusions}

The plant-based natural coagulants showed the ability to remove turbidity. However, only 2 plant-based natural coagulants achieved more than an $80 \%$ turbidity removal rate. The water quality was achieved at a class IIA standard, which means the turbidity was lower than 50 NTU according to the National Water Quality Standards for Malaysia. The effect of different parameters on the relationship between the turbidity removal rate An increase in plant-based natural coagulant dosage will increase the efficiency of the turbidity removal in the water. The high alkaline water decreases the effectiveness of plant-based natural coagulants. The agitation and contact time show the importance of the coagulation process. The coagulation process requires rapid mixing at more than $80 \mathrm{rpm}$ and the contact time should not be less than $20 \mathrm{~s}$. Use of plant-based natural coagulants for water purification did not affect the final degree of $\mathrm{pH}$ because the plant protein is an amphoteric substance. Therefore, it can eliminate the need for additional $\mathrm{pH}$ adjustment for the treated water.

\section{Acknowledgments}

The authors thank Curtin University Malaysia for facilitating this study. Collaboration from King Saud University, Saudi Arabia is highly appreciated.

\section{Competing Interest}

There is no competing interest to declare.

\section{References}

[1] Aqueduct Water Risk Atlas. World Resources Institute. 2013. https://www.wri.org/resources/maps/aqueduct-water-risk-atlas.

[2] Haftendorn, H. (2000). Water and international conflict. Third World Quarterly, 21, 51-68.

[3] Oyanedel-Craver, V.; Smith, J.A. (2007). Sustainable colloidal-silverimpregnated ceramic filter for point-of-use water treatment. Environmental Science \& Technology, 42, 927-933. https://doi.org/10.1021/ES071268U.

[4] Ndabigengesere, A.; Narasiah, K.S. (1998). Quality of water treated by coagulation using Moringa oleifera seeds. Water Research, 32, 781- 791. https://doi.org/10.1016/S00431354(97)00295-9. 
[5] Patale, V.; Pandya, J.; Mehta, K. (2012). A preliminary study on abelmoschus esculentus fruit mucilage extract as coagulant-flocculent for turbid water treatment. Pollution Research, 31, $217-$ 221. http://dx.doi.org/10.1007/s13762-013-0282-4.

[6] Bodlund, I.; Pavankumar, A.R.; Chelliah, R.; Kasi, S.; Sankaran, K.; Rajarao. G.K. (2014). Coagulant proteins identified in Mustard: a potential water treatment agent. International Journal of Environmental Science and Technology, 11, 873-880. http://dx.doi.org/10.1007/s13762-0130282-4.

[7] Gassenschmidt, U.; Jany, K.D.; Tauscher, B.; Niebergall, H. (1995). Isolation and characterization of a flocculating protein from Moringa oleifera Lam. Biochimica et Biophysica Acta (BBA)-General Subjects, 1243, 477-481. https://doi.org/10.1016/0304-4165(94)00176-x.

[8] Choy, S.Y.; Prasad, K.M.N.P.; Wu, T.Y.; Raghunandan, M.E.; Ramanan, R.N. (2014). Utilization of plant-based natural coagulants as future alternatives towards sustainable water clarification. Journal of Environmental Sciences, 26, 2178-2189. https://doi.org/10.1016/j.jes.2014.09.024.

[9] Li, T.S.; Tan, H.Y., Perera, C. (2006). The coagulating effects of cations and anions on soy protein. International Journal of Food Properties, 9, 317-323. https://doi.org/10.1080/10942910600596340.

[10] Gregory, J. (2009). Monitoring particle aggregation processes. Advances in Colloid and Interface Science, 147, 109-123. https://doi.org/10.1016/j.cis.2008.09.003.

[11] Yin, C.Y. (2010). Emerging Usage of Plant-Based Coagulants for Water and Wastewater Treatment. Process Biochemistry, 45 1437-1444. https://doi.org/10.1016/j.procbio.2010.05.030.

[12] Choy, S.Y.; Prasad, K.M.N.; Wu, T.Y.; Ramanan, R.N. (2015). A review on common vegetables and legumes as promising plant-based natural coagulants in water clarification. International Journal of Environmental Science and Technology, 12, 367-390. http://dx.doi.org/10.1007/s13762-013-0446-2.

[13] Jones, A.N. (2017). Investigating the potential of Hibiscus seed species as alternative water treatment material to the traditional chemicals. Doctoral Thesis, University of Birmingham, Birmingham, UK.

[14] Katayon, S.; Noor, M.J.M.M; Asma, M., Thamer, A.M.; Liew Abdullah, A.G.; Idris, A.; Suleyman, A.M.; Aminuddun, M.B.; Khor, B.C. (2004). Effects of storage duration and temperature of Moringa oleifera stock solution on its performance in coagulation. International Journal of Engineering and Technology, 1, 146-151.

[15] Okuda, T., Baes, A.U.; Nishijima, W.; Okada, M. (2001). Isolation and characterization of coagulant extracted from Moringa oleifera seed by salt solution. Water Research, 35, 2, 405-410. https://doi.org/10.1016/S0043-1354(00)00290-6.

[16] Yuliastri, I.R.; Rohaeti, E.; Effendi, H.; Darusman, L.K. (2016). The use of Moringa oleifera seed powder as coagulant to improve the quality of wastewater and ground water. IOP Conference Series: Earth and Environmental Science, 31, 012033. http://dx.doi.org/10.1088/1755$1315 / 31 / 1 / 012033$.

[17] Tunggolou, J.; Payus, C. (2017). Application of Moringa oleifera Plant as Water Purifier for Drinking Water Purposes. Journal of Environmental Science and Technology, 10, 268-275. https://dx.doi.org/10.3923/jest.2017.268.275.

[18] Sasikala, S.; Muthuraman, G. (2016). A Laboratory Study for the Treatment of Turbidity and Total Hardness Bearing Synthetic Wastewater. Ground Water Using Moringa oleifera. Ind Chem Open Access, 1, 112. http://dx.doi.org/10.4172/2469-9764.1000112.

[19] Sánchez-Martín, J.; Beltrán-Heredia, J.; Peres, J.A. (2012). Improvement of the flocculation process in water treatment by using Moringa oleifera seeds extract. Brazilian Journal of Chemical Engineering, 29, 495-502. http://dx.doi.org/10.1590/S0104-66322012000300006. 
[20] Jaoudi, M.; Amdouni, N. (2013). Coagulation Treatment by $\mathrm{Al}_{2}\left(\mathrm{SO}_{4}\right)_{3}$ and Residual $\mathrm{Al}$ Determination in Medjerda Water Dam (Tunisia). Journal de la Société Chimique de Tunisie, 15, 175-181.

[21] Vieira, A.M.S.; Vieira, M.F.; Silva, G.F.; Araújo, Á.A.; Fagundes-Klen, M.R.; Veit, M.T.; Bergamasco, R. (2010). Use of Moringa oleifera seed as a natural adsorbent for wastewater treatment. Water, Air, \& Soil Pollution, 206, 273-281. http://dx.doi.org/10.1007/s11270-0090104-y.

[22] Cai, T.D.; Chang, K.C. (1998). Characteristics of production-scale tofu as affected by soymilk coagulation method: propeller blade size, mixing time and coagulant concentration. Food Research International, 31, 289-295. https://doi.org/10.1016/S0963-9969\%2898\%2900091-X.

(C) 2021 by the authors. This article is an open access article distributed under the terms and conditions of the Creative Commons Attribution (CC BY) license (http://creativecommons.org/licenses/by/4.0/). 